19 Revue d'histoire du XIXe siècle

Société d'histoire de la révolution de 1848 et des

révolutions du XIXe siècle

$6 \mid 1990$

Le XIXe siècle en question

\title{
Les blanquistes à New-York (1871-1880)
}

Michel Cordillot

URL: http://journals.openedition.org/rh19/49

DOI: $10.4000 /$ rh19.49

ISSN: $1777-5329$

Publisher

La Société de 1848

Printed version

Date of publication: 1 June 1990

ISSN: 1265-1354

Electronic reference

Michel Cordillot, « Les blanquistes à New-York (1871-1880) », Revue d'histoire du XIXe siècle [Online],

6 | 1990, Online since 09 September 2008, connection on 01 May 2019. URL : http:// journals.openedition.org/rh19/49; DOI : 10.4000/rh19.49

This text was automatically generated on 1 May 2019.

Tous droits réservés 


\title{
Les blanquistes à New-York (1871-1880)
}

\author{
Michel Cordillot
}

\section{ABSTRACTS}

No abstract available by now

Pas de résumé disponible actuellement

INDEX

Mots-clés: New-York, Blanquistes 